\title{
“To Understand Russia”? Question about Russia as a Philosophical Problem
}

\author{
Marian Broda \\ Department of Central and Eastern Europe, University of Lodz, Lodz, Poland \\ Email: brodamarian@uni.lodz.pl
}

Received 23 August 2014; revised 20 September 2014; accepted 6 October 2014

Copyright (C) 2014 by author and Scientific Research Publishing Inc.

This work is licensed under the Creative Commons Attribution International License (CC BY). http://creativecommons.org/licenses/by/4.0/

(c) (i) Open Access

\section{Abstract}

The aim of this article is to identify and explain the cognitive possibilities which-for the sake of analysis of the questions about Russia and the efforts to "understand Russia", for centuries central to the Russian intellectual and cultural tradition-are offered by the post-Kantian philosophical perspective. The fundamental research method is the analysis of texts in which representative members of the Russian philosophical and broader intelectual-cultural tradition undertake selfcoqnitive attempts, asking questions about Russia. The analyses which I have undertaken, show that in the post-Kantian theoretical perspective it is possible to strive for recognition of the basic assumptions, structures, properties and conditions of the sense-making processes, which are invisible for such a subject, which is directly involved in a specific cognitive relation. It is then possible and required to determine which forms and structures can appear-and why-within those basic assumptions or conditions as important-from the perspective of subject, object or axiology-the recognition of factors, conditions and limits of heterogenization of the basic structural and substantial solutions, the recurring relations of senses and the types of their specifications, and the scope and methods of permitted self-problematization. In conclusion, I wish to state that the questions about Russia are, therefore, truly questions of their authors about themselves and their way of understanding the world.

\section{Keywords}

Russia, Russian Soul, Question, Self-Knowledge, Philosophy, Tradition, Post-Kantian Perspective, Intention, Objectivity, Identity Non-Identity

\section{Introduction}

Dostoevsky’s motherland is a country where for centuries questions about Russia have been permanently reformulated and new efforts aiming at a recognition and determination of its definite identity have been reiterated. 
What is more, these are frequently considered as being the most fundamental matter, for-in the opinion of their multiple authors - the possibility to seek independent solutions for specific philosophical, cultural, social or political problems, ones which would be autonomous from this matter, is doubted. The primary motif of many similar attempts is the finalistic perceived concept: "to understand Russia". This notion is expressed directly or can be revealed both in the concepts of Russian philosophers, thinkers or writers, but as well in the common perceptive and conceptualist schemes of subsequent generations of Russians and in the type of discourse they perform (Broda, 2005: pp. 24-32).

Certainly, Russian philosophy and thinking cannot be reduced only to questions about Russia-even if the attempts to define their identity through the question "what is Russia?” take an especially significant place in their intellectual and cultural tradition. However, centrality of the concept of the nature of Russianness, and most of all - the real impact of the presumed answer to this question onto the more basic assumptions and conclusions of the given philosophical concept is usually much more significant than their apparent external structure would suggest. This is facilitated by the tendency, deeply rooted in Russian thought and culture, to recognize in Russia "the soul of the world" — a special "microcosm" or world model—and to recognize in Russian man-the model of mankind (Solov'ev V. M., 2001: p. 92). Watching from a similar perspective, particular questions about Russia, Russians and the "Russian soul" become universal, and de facto become the questions about the world and humanness as a whole. On the other hand, it can be expected that the level of centrality, vitality, character and shape of the questions about Russia, related cognitive efforts and the type and content of sought answers mayand should—be explained by the properties of the wider cultural, mental and spiritual context, in which they appear. Especially, it can be expected, what has been proven by my previous research, that the finalistically perceived imperative "to understand Russia" is based on such genotypical properties of Russian culture and mentality (Broda, 1998: pp. 44-54, 87-103; Broda, 2001: pp. 290-314).

The aim of this article is to show and explain generally the cognitive possibilities, which-for the sake of analysis of, for centuries central to the intellectual-cultural tradition, questions about Russia, especially these set by finalistic idea to "understand Russia"-are offered by the post-Kantian philosophical perspective.

The fundamental research method is the analysis of texts in which representative-the great, the influential and the typical-members of the Russian philosophical and broader intellectual-cultural tradition undertake selfcognitive attempts, asking questions about Russia, as well as an analysis of Russian utterances where similar efforts constitute the subject of attention and reflection. Of a supplementing character are the analyses aiding in a fuller understanding of the connections of the analysed thought systems with their socio-cultural substratum, as equally the functions that they play in the consciousness and actions of individuals as well as in the sphere of collective, intellectual, social and political life.

Fulfilling the research plan, in the subchapter The subject, the object, the cognitive relation-mystery I illustrate that, formulated for centuries, Russian questions about Russia are not de facto "external" to their subject, but they assume it already in their outline. In the subchapter Russia—the "soul of the World" I analyze-on the example of chosen concretization of the examined ways of perception and understanding the world-the basic problems concerning the way Russia and Russianness are understood in terms of a "soul". In the subchapter The Russian riddle/mistery I explain why answers formulated by Russians to the questions about Russia still oscillate-referring to each other-between understanding Russia in terms of a "riddle" and a "mystery." In the subchapter Self-reproduction paradoxes and mechanisms I show why the Russian attempts to understand Russia generate at the same time auto-negating mechanisms on the one hand and self-reproductive processes on the other. In the conclusions, I sum up to diagnose that posing questions about Russia the authors truly ask about themselves, especially about their way of comprehending, conceptualizing and problematizing reality.

In philosophical terms, the theoretical and methodological fpoundation for the research I have conducted is, presented by the Polish philosopher Marek Siemek, the interpretation of Kantianism as a proposal of-juxtaposed with, typical for the pre-kantian philosophy, epistemic-epistemological viewpoint. The undertaken research, whose basic assumptions, results and conclusions I present in this article, are my own proposal of the analysis of philosophy and Russian thought from a programmatically post-Kantian perspective i.e. precisely from the epistemological standpoint. The results of successive research are presented, in reference to the general features of philosophy and Russian thought, among others, in books Poniat' Rossiju?, Russkije woprosy o Rossii, Historia i eschatologia. Studia nad myśla Leontjewa i "zagadka Rosji” i "Zrozumieć Rosję"? O rosyjskiej zagadce-tajemnicy), and in application to the analysis of particular world-view formations in books Narodnickie ambiwalencje. Między apoteoza ludu a terrorem oraz Mentalność, tradycja i bolszewicko-komunistyczne 
doświadczenie Rosji.

\section{The Subject, the Object, the Cognitive Relation}

For many years, Russian self-cognitive efforts have been analyzed and explained in categories of philosophy, sociology, psychology, cultural studies, the political sciences, history, literature studies, etc. Russian questions about Russia can also be the subject of heuristically fertile philosophical analysis, especially when the conducted research utilizes the cognitive possibilities offered by the transition from a passive to active concept of cognition, as proposed by Kantian transcendentalism. Every cognitive attempt determined by, understood in a certain way, question about Russia, emerges then as a co-constituting the explored subjectivity subjective act: mental, philosophical, ideological, world-view, etc.; often also-although not explicite-sacral or quasi-sacral. Found, as the result, "essence" and "subjectivity" of Russianness are not the "entity in itself," something external to the activated sense-formation processes, but they constitute the correlate of particular subjective intention (Siemek, 1982: pp. 17, 42-44). The question about Russia is not "external” to its subject, but it assumes it already in the fundamental framework. Realizing the above-requiring the assumption of epistemological viewpoint (and not, immersed in its directness in the "subjectivity", epistemic), able to see the interdependence of both members of subject-object cognitive relation-creates a possibility to identify and problematize general frames which it $a$ priori determines for the Russians' sphere of self-cognitive efforts and subjective order which they recognize, assuming it beforehand as significant, true and real in the important general outline.

The extent of centrality of questions about Russia-especially those determined by the finalistic imperative of its understanding - in the local intellectual tradition is defined by the extent to which the analysis can become, at the same time, the "critique of Russian reason" (in the Kantian notion of "critique") in general, recognition of the assumed cultural a priori, and even the way and character of its possible problematization. Every culture has its own particular order and topography of sense, which-usually forgetting about the already made projection-it recognizes in the world as natural, true or real; unlike the others, perceived as foreign, arbitral, untrue, unreal etc. At the same time, it is then settled, what can appear, or not, as obvious and understandable, and what, and in what way, becomes a problem, is not perceived as a problem or consciously remains outside the sphere of undertaken problematization (Broda, 2001: pp. 225-227). As a result of the above, the analysis of the questions about Russia is not only the analysis of the Russian reflection over the cultural identity of Russianness, but also- to the extent to which the later co-constitues itself through them and expresses itself-the analysis of the identity itself and the interdependence of them both.

The analyses I have conducted so far, whose subject-matter I can only mention here, of Russian questions about Russia and the self-cognitive attempts connected with these, included the detailed aims connected with their research cover the identification and analysis of the general premises and conceptualised-axiological structures present-formulated explicite or assumed —in the said questions and attempts; the fundamental variants of Russian self-cognitive aspirations and dimensions, the causes and conditionings of differences and similarities between them; of the religious, cultural, social, mental historical context within which similar questions and attempts have revealed themselves, while in particular of their involvements in the more universal experience of sacrum and the more general structures of myth, of the presence within them of archaic contents; of the influence of the Orthodox and post-Orthodox religious-cultural substratum on the shape and character of the attempts examined; of the presence and influence of the Western intellectual-cultural context on Russian self-identificational efforts; of the premises and factors jointly deciding on the central place as well as the vitality and directions of the evolution of self-cognitive aspirations within philosophy, thought, tradition and Russian culture; of the world outlook, ideological and social functions and equally of the consequences of a similar way of thinking in Russia and the stances associated with it in the processes of transformation and in the character of the Russian collective; of the manifestations and means of sensing the presence or making themselves aware on the part offorced "understandings of Russia" - the authors of the said questions to the manifold problems that are linked to them.

The realisation of the above enumerated research aims is at the same time accompanied by the acceptance of two fundamental research assumptions. Within the thinking of the first, given that within Russia for centuries there have remained-treated as a fundamental question-self-cognitive attempts, then the concentration of research attention on their analysis creates a heuristically fertile cognitive perspective, one vital for research into Russian thought and philosophical self-knowledge, as well as equally research into the wider intellectual-cul- 
tural tradition, into social self-consciousness, identification processes etc. In accordance with the second in so far as the motif of many-placed within the centre of that very intellectual-cultural tradition-self-cognitive attempts remains the finalistically comprehended intention "to understand Russia", then the examination of the premises which consciously or unwittingly accompany it is important equally for a fuller interpretation of they themselves, as equally for a better understanding of a more general order or topography of meaning, specificpresent within it or positioned by it - to the Russian self-awareness and culture (Broda, 2011: pp. 22-24).

The research of Russian thought, tradition and self-conscience, and in particular the research of the self-cognitive pursuits they include-i.e. the attempts to recognize and define Russian own identity-evidently show that questions about Russia posed there are not neutral in relation to their object (in relation to what they perceive and recognize as their object), and neither is the object neutral towards them. Each cognitive attempt established by means of a question about Russia and the finalist attempt to understand it or prove its intellectual ununderstandability irrevocably remains an act, which is subjective, philosophical—and often quasi-religious, or even mystical. The "nature" or in general the "objectivity" of Russianness discovered as a result of such actare not something remaining outside of the launched sense-making process, but constitute a correlate of a specific culture-forming intent.

To reveal this intent, to ask about its direction and sense is to perform a problematization of the established self-cognitive pursuits of Russians and of the objective order which those pursuits acknowledge-and which is assumed implicite in advance as a real and true order. The object and subject of the cognitive relation co-assume and co-constitute each other as results of specific sense-making processes directed-in the considered case-by the intent "to understand Russia" and simultaneously "to understand oneself" by the subject asking about Russia (and also about the world, history, truth, good, beauty, worldliness, eternity, etc.) in such a specific manner. For example: the foundation of distinctiveness, identity and community of Narodnism as a whole, and Narodnik viewpoint in particular, is determined by the intelligentsia's intension (for this reason Narodnik) to achieve selfdetermination as an act fundamentally and necessarily mediated by their attitude to the Russian people. The contents of this intention assume a priori particular generally defined, common, and at the same time, specific order of sense, expressing Narodnik subject's attitude to the world, its country and itself. As a consequence, it is forejudged how in Narodnik idea of the world not only the people, intelligentsia and their mutual relationship, but also the society, law and the mechanism of its development, the state, economy, culture, and so on, may appear. That is by subjective intention's gaining its intellectual and axiological legitimization and the foundation of social reality (Broda, 2003: pp. 130-144).

\section{Russia-The "Soul of the World"}

A very common, practically central and especially cultivated in the communal tradition and social conscience of Russians is the notion of "soul", applied to define and express the nature of Russianness and Russia itself. Russians on the whole emphasis the indeterminacy, the unfathomableness, the incomprehensibility, the mysteriousness or mystery of the "Russian soul". Simply the very formulation of "the soul"-one so eagerly used for ages in reflections upon the subject of Russia-is saturated with a rich archetypal, though far from arbitrary, content. In differentiation from reason and spirit, the "female" soul is something more physical than they, that extends beyond rationality and spirituality, being more directly connected with materialness, with the heart, the emotional sphere, morality etc.; it is located between-in the centre-the remaining dimensions of existence. And what is more, it is the basis of their potential unity, overcoming isolation, mutual alienation and conflict (Ryabov, 1998: pp. 34-36). In constituting the soul of the micro- and macro-world, the source of its changes and transformation, it reveals, however, also certain self-destructive traits: tendencies to divisibility and multiplicity, inseparable from all materialization, creation and reproduction. The 'soul' does not simply represent life, but an active element of power. The disclosure of the presence and power of sacrum is its manifestation. It gives unity to reality, it fulfils holiness in it (Circlot, 2000: p. 119).

Penetration into the depths of the "Russian soul" and the "soul of Russia" is experienced as contact with holy reality, giving it-independent of attempts made at times at a secondary rationalization and philosophization-a mythical-religious meaning. On the other hand, which equally results from the same, explicated above, meaning of the concept of "soul", the manifestation of "the essence of Russianness", the Russian mission, the means for national existence consistent with it, the state of awaited fulfillment etc., cannot limit itself to a purely spiritual triumph, or the expanding of merely moral or intellectual arguments, but has to contain at the same time its ma- 
terial dimension: a comprehensive and total manifestation of power. Always, even during the Time of Troubles, the hope of a reactualization accompanied them—and immortalization—of the situation in which "God not only saved Russia from ruin, but constantly increased her strength and made out of her the most powerful and most famous of all the nations on Earth" (Serafim, 1992: p. 10). The micro (anthropological) and macrocosmic pole appear in their sphere as integrally coupled and isomorphic: "the Russian soul" in its anthropological dimension finds, because it founds it, its cosmic equivalent in the "soul of Russia". Each of these-in its own scale-possesses related possibilities. The role that the soul fulfills on the microcosmic level prevailing over other components of the structure of human existence, enlivens, unites and transforms the anthropological whole, on the macrocosmic level is ascribed to Russia-in as far as Russia, in realizing its potential, fulfills the role of "soul of the world". The mediation between the various dimensions of existence: the overcoming of isolation and also the opposition of spirit and matter, values and interests, eschatology and temporality, the opening of a universal perspective enabling the overcoming of one-sidedness, reconciliation of contradictions, the achievement of unity and plenitude constitute the particular capacity and mission of both sides.

As F. Dostoevsky believed that a Russian can instinctively make out "the universal trait even in the most glaring personalities of other nations, instantly will unite them, reconcile them in his own idea, find room for them in his thought system and often discover a point of contact and agreement in the ideas of two different nations, ideas that are totally opposite and that are in rivalry with each other...” (Dostojewski, 1982: vol. 1, p. 61). Nobody else can replace him in this role because "only the Russian soul has received as a gift a universal nature, a mission for the future: to explore and unite the whole multiplicity of nations and to remove all the contradictions between them,” (Dostojewski, 1982: vol 3, pp. 209-210) as a consequence of which "Russia's mission is to proclaim the ideas of a universal union of the world and common human love” (Dostojewski, 1971: p. 356).

From the viewpoint of the universal character of the "Russian soul". reflection upon it, the experience of its "mysteries" or the working out of the riddle ascribed to it, these take on-which presents the subsequent aspect of the idea of "Russia-the soul of the world"-universal values: "Why have dozens and hundreds of the most intelligent people in Europe sought comfort, and have seen hope, in Russia? Why have they, even if enigmatic, sought the soul here? Is this not because, despite all of its shortages, a Russian will answer the main intention that relates to man in general?” (Solov'ev V. M., 2001: p. 91).

Attempts by Russia to fulfill the role of "soul of the world' bring however simultaneously into motion-concealed or perceived as initiatory challenges-processes and mechanisms of self-negation. This role brings with it both a sense of the greatness, exceptionalness, and universality of Russia as well as a sense of the dangers lurking in wait: "In the way that in the soul of the natural world and in the soul of a particular man the clear spiritual principle has in opposition to it a dark chaotic basis, which has not yet been overcome, still not subordinated to higher forces, - which still fights for superiority and is inclined towards death and destruction, so too, of course, is the case in the collective soul of humanity, i.e. in Russia” (Solov'ev V.S., 1994: p. 373). In the world of history the more there is a strengthening to realize the universal, uniting or guiding mission of Russia the greater it follows to struggle with size, heterogeneity, resistance, devolutionary tendencies etc. The external irascibility and decomposition elements are then transferred to the inside, and actions designed to overcome them exhaust the strengths of the country.

Understanding Russia in categories of the "soul of the world"-constituting a relic of an archaic means of experiencing one's own community and territory as "the centre of the Earth", holy reality, the area of contact between the terrestrial and the Transcendental-answers well the preserved intuitions of Russians on the subject of their country, its place and aim of existence in the world as well as, consequently, they themselves. RussianOrthodox implementations of this experience are in particular the motive of Moscow the Third Rome and certain variants of the Russian idea (Broda, 2007: pp. 12-13, 18-19, 30-31).

\section{The Russian Riddle/Mystery}

It should be noted that the finalistic attempt "to understand Russia" is accompanied, often unconsciously, but also inevitably, by a respective projection of sense, which a priori assumes a determined order of reality. It happens both when this concept is referenced in the meaning of Sisyphus' torment, and when it is declared —or at least it is believed-that the answer, the ultimate solution of the "Russian riddle", explaining the depths of "the Russian soul" or the meaning of "the Russian idea" exists and can be found. In the first case, a special nature for Russia is assumed, which excludes the possibility of understanding or learning this nature: "all, that is historical, 
the life-related and psychological matters are-as symptomatically points out the Russian philosopher Semyon Frank - only an external covering, temporary adopted bodies, a passing modality of her (i.e. of Mother Russia's) hidden face, which is visible only for God” (Ryabov, 1998: p. 37). In the second case, while remaining at the belief of the special nature of Russia, it is discussed as a phenomenon which-by the power of its inherent dynamics-reveals its eschatological identity for the chosen ones-and therefore a feeling of national and supranational mission may flow upon those chosen ones and Russia. This is the way of e.g. Vladimir Solov'ev, considered to be one of the greatest Russian philosophers, who explains: "The Russian idea, Russia's historical obligation requires us to acknowledge our unbreakable liaison with the universal family of Christ and to turn all our national talents, all the powers of our empire toward the final realization of the social trinity, where each of the three main organic unities - the Church, the state and society—are unconditionally free and powerful, not in separation from the two others, but through reinforcing the unconditional inner liaison between them. To reflect on earth this exact image of the Godly trinity—-this is what the Russian idea is about” (Solov'ev V. S., 1991: p. 82).

Both in the first and the second case, the intent to understand Russia is related and co-determined by the intent to understand oneself, and the statement of the unrecognizability of the "soul" or "nature" of Russia or, on the contrary, a presentation of the solution to the "Russian riddle" bring about, respectively, analogous responses to the questions as to the nature of the subject, about specificity and the ability to understand the "Russian soul", to allow Russians to understand themselves. In both cases, the resulting descriptions de facto do not relate-as their authors would wish—to the presumed, seemingly absolute, cognitive subject neither to the being in itself, but to the subject and objectivity, constituting mutually linked and conditioned correlates of a specific cognitive relation.

For the Russian conscience, poorly transformed by Kantism, the fact of a previous sense-making projection, co-constituting the researched "reality", and also the act of the performed selection of objective and axiological sense, remain beyond the field of vision. The subjective-in the negative meaning of "subjectivity" — character is compared only to other, alternative self-cognitive attempts, which are denounced as "custom", "superficial", "untrue" or "missed", and to the own attempt of the subject, in which-as it is believed—the very Russia is personified and expressed. The absence, weakness or transformations of Kantian ideas in Russia, resulting in a changing of its original sense, and also the failure to notice the subjective moment in the shape of recognized Russian objectivity in general are supported by numerous phenomena strongly present in Russian culture and thought: mystical realism, anti-phenomenalism, ontologism, cosmism, orientation to totality, community-oriented anti-individualism, maximalism, etc. (Broda, 2005: pp. 65-68, 83-84, 103-108).

Acknowledging the subjective moment or even the character of own findings-coexisting with other, alternative, so in a sense equivalent findings on the nature of Russianness or reality in general is not facilitated by a characteristic strong Russian unwillingness to notice any distance between the recognizing subject and the object of cognition, between thinking and the object of thinking. As shown by Italian scholar, Vittorio Strada, there is "a vicious circle" functioning inside "the Russian riddle": questioning intellectuals try to understand Russia, define the nature of its past and future. On the other hand, Russia with its past and presence shall define the intellectuals themselves, with all their attempts to define Russia and Russian "idea" or "fate". If you stay within this vicious circle, one can endlessly walk the perimeter and intoxicate one's mind with one's and Russia's "specificity", "inconceivability" and "enigma", thus only recreating the ever existing—because assumed-initial situation (Strada, 1996: pp. 23-24). To break this vicious circle of "the Russian riddle" is not an easy matter. This due to (what is characteristic for Russian thinking) unwillingness to accept any distance between the learner and the subject of cognition-between the thinker and its subject. Russian tradition tells you to "think the things thought”, "think the subject of the thoughts", not to explain, but rather to personify (Faryno, 2001: p. 378).

It is not incidental that sophic thinking becomes an ideal, and sophiology—a privileged system of knowledge: "Sophia" is immanent to all existence, and its reflexivity is manifested, as it is believed, in its ability-unique only to itself alone- "to think with its own self". This particular cult of Sophia present in the Russian tradition is a proof of the sacral or quasi-sacral character of the sought knowledge and certain hopes it arises. If the knowledge is found, the hopes promise to overcome the isolation, national or universal regeneration, restoration of identity, final discovery of the self, etc. It is the need to contact the sacred reality, not bound by divisions and polarizations from the sphere of profanum, with experience, which cannot be described with concepts, with reality accessible only through a certain emotional reaction arisen in the self, which experience it (Sarnowski, 1982: p. 85). Understanding of the words articulating the contents of updated experience of Russian sacrum converges with the feeling of participation in sacral or quasi-sacral reality and with moral obligation (Kołakowski, 1998: 
pp. 190-192). A Human being, who underwent this experience feels at the same time: dependency on sacrum, alienation from everything, which is not concurrent with sacrum, unification within sacrum and, as a result, a certain salvation-liberation. It does not seem that this could be a permanent act for human being, who is after all involved also in the sphere of profanum - and perhaps it is merely an illusion or fantasy.

The inevitable disappointment is even bigger, now the experience of depth of Russian "mystery" and drama of own helplessness towards it is available. This disappointment leads to next attempts to tackle the "Russian riddle”, etc. Those attempts are not only performed by Russian thinkers/mystics; they are also more or less conscious basis and framework for reflections of millions of Russians about their own identity and spiritual/social order offering a place for their country and themselves. The effort made by thinkers and Russian authorities to find a formula of new Russian concept-able to replace the existing chaos with higher order, the division with unity and the helplessness with might-go in a similar direction. The most sensitive of Russians show that such striving is not free of dramatic tension caused on one side by the will to find any moral/axiologic absolute and to possess the exclusive, all-assuming "higher" truth, and, on the other side, the fear of loss of self-containment and the deprivation of personal moral responsibility (Kelly, 1978: pp. XVI-XVII).

As long as you stay within the closed circle of ,the mystery/riddle”, there is no space for critical distance towards own mental constructs, for self-awareness. There is no space for the ability to understand the fact of subject projection of meaning made earlier-thus also, the choice of meaning made earlier.

However, this is not an incidental situation. Russian mentality, culture or reality on general-grown on the soil of Orthodox religion-shows much stronger eschatological intensity than in the West. It seeks fullness, total reintegration, which would be able to overcome the universal diversity seen as the result of the Fall, the challenge and the temporary condition: the diversity of multiple spheres of life, types of knowledge and orders of meaning. This mentality reinforces the need of urgent totalization of meaning and parallel tendencies to direct connection of social, political, economic, religious or historiosophic issues with philosophical questions. There is trend to blur the boundary between the sacrum and prophanum, religion and ideology, eschatology and politics, theory and practice, scientific analysis of social dynamics and historiosophy, etc. The term "truth" is contaminated with elements related to esoteriological, eschatological (or quasi-eschatological) ethics, aesthetics, historiosophy, ideology, etc. (Sutton, 1988: pp. 7-8). To put things with a certain exaggeration: all elements permeate and overlap all others. The entire multiplicity of experienced reality is more directly related to the alleged "essence" or "center", which determine-as it is believed-the special identity of Russia (and therefore on the special mission it bears, the fate of its past and future history, etc.). Reaching the essence or the bottom of Russianness is not only a cognitive or rational action. It includes some elements of sacral experience and the related desire of spiritual and material transformation.

Russian conscience is only poorly aware of Kantian heritage. The fact of meaning-forming projection performed earlier, which helps to constitute the researched "subjectivity", and also the act of choice of meaning made by the individual (even unconsciously) are hardly ever in the field of vision. This absence, weakness or transformation-usually distorting the original sense-of Kantian ideas in Russia, and also the failure to present the subjective moment in the Russian cognitive objectivity in general are an effect of some elements strongly present in this culture and thinking. These are elements of mystical realism, antiphenomenalism, ontologism, cosmism, orientation for totality, community-based anti-individualism, maximalism, etc. These elements were grown on the basis of Eastern Christianity, and in the era after Peter the Great, they were in many cases strengthened by the conscious or instinctive turn towards ideas and values alternative to the Western ones (Andreev, 1970). Subjective-in the negative meaning of "subjectivity" — character is assigned only to the other, alternative cognitive and Western attempts, described as "customary”, "superficial”, "external”, "untrue” or "missed”and not with their own attempt, in which as it is believed, the Russia itself and its "soul”, "concept”, "mystery” or just solved "riddle" is present and expressed.

\section{Self-Reproduction Paradoxes and Mechanism}

The self-cognitive efforts of Russians combine in themselves as a rule the elements of sacral experience and profane experience, elements of holy knowledge and secular knowledge, which to a large degree decides about the character of the conceptions articulating them as well as the results-and also the illusions and mystifications connected with it-of attempts to bestow on them religious sanction or the substantiation of their exclusive authenticity within purely rational categories. Axiological-theoretical constructions typical for Russian questions 
about Russia and the accompanying self-cognitive aspirations, the imperceptibility of the moment of the joint creation of "the essence" of Russianness through each applied cognitive instrument, the conceptualised schemes etc. as well as the conviction of their authors that they express Russianness as about-identified within its alleged profundity-being alone in itself, are some of the important sources of the mutual opposition of particular conceptions, aspiring to an exclusive "understanding of Russia".

There hides in many cases, however, behind the mutual opposition of particular explanations of the essence of Russianness, the determinants of its identity emphasised by their authors, their extremely fundamental similarity resulting from the fact that they are positioned within the frameworks of a mutually assumed generalised plane of meaning, the analysis of which aids in the explanation of not only the polarity of the said explanations but also their dynamics and mutual interaction, the transfer of one set of oppositions into others, their attempts at "a higher synthesis" etc. The formulation of the essence of Russianness, strongly grounded and displayed amongst Russian self-cognitive attempts, within categories of "the soul" (as equally its varied equivalents and metamorphoses), similarly the oscillation of thinking about it in the framework of the dynamic opposition "riddle-mystery" are not accidental or arbitrary, having their bases within the whole set of traits jointly creating the religious-cultural and spiritual-mental "genotype" of Russia, which to a significant degree determines their character and the borders of openness in the extra-intellectual historical context as well as the shape of gained and accepted answers to questions about Russia. Important reasons for the contemporary identity crisis for Russia and Russians-next to a series of other factors, political, civilizational etc. - are linked, among other things, with the limited adaptability of the created and still vital mental and cultural archetypes (Russia- "the soul of the world", Moscow the third Rome etc.) to the contemporary consciousness, cultural, social, political etc. changes in the world.

Analysis of Russian self-cognitive efforts and self-realization pursuits reveals a symptomatic paradox: those tendencies, even though established through a search for the final totality, unity and identity, de facto explain and petrify the experience of Russian reality in categories of "sleep", "temporality", "rift" and "lack of identity". The presumed, in different manners, and strongly sought Russian "identity" ("idea”, "soul”, "riddle", "mystery"...) in fact remains-never permanently updated in reality-a mythical mental design. The historical sociocultural or spiritual/intellectual reality of Russia can be effectively described and analyzed through the experience of breaking, lack of identity and the attempts to retrieve it. To use a lunar metaphor, not far from the Russian type of awareness: Russia is like the Moon-more than anything, it is a being, which is never identical with itself (Cirlot, 1971: p. 211). Therefore, we have to deal with "an identity of unidentity" — strongly rejected, but an even more intensely present characteristic which perhaps most accurately describes and explains the modern and contemporary mental and cultural face of Russia. It especially helps to describe and explain the type of selfconscience still frequently dominant in common thinking and discourse, and also in the Russian mental formations and philosophical concepts.

It is no accident that Russians permanently undertake new attempts at self-cognition and self-realization: the planned turn to Reality, its hidden depth and inner nature-marginalizing the significance of empirical knowledge and factors, conditions or development mechanisms available at the empirical level-in the recurring practice of Russia's historical experiences as an act of transgressing to the outside of reality. The underestimated sphere of phenomena (empirical, common, profane) each time takes revenge and runs the processes of the destructive verification of subsequent formulas of the realization of the Russian nature, soul, idea... (Broda, 2002: pp. 21-23, 26-29, 32-35).

Mechanisms of reiterating the auto-destruction of a similar aspiration and pursuits are not limited only to the mental and cognitive sphere. First of all, due to the sacral or quasi-sacral character of the sought knowledge and the hopes related to the finding of this knowledge-colliding with the reality of the profane, historical worldthe hopes to overcome alienation, to achieve community regeneration, a retrieval of identity, to finally become oneself and find oneself. Secondly, because the Russian conscience, perceiving Russia in categories of "soul” and especially "the soul of the world" in its visions of community-based self-fulfilment irrevocably combinesand as a result opens for historical and social verification - the spiritual and material dimension, ethical concepts with executive power, national elements with universal ones, and assumes the full and final "realization" of the related values and contents.

Russian attempts to appear in the role of "the soul of the world" -in this or another understanding - (the beginning of the Heavenly Kingdom on earth, the Third Rome, the centre of a panhuman communist society...)which would lead other communities and join it into Russian self-fulfillment projects, exceeding the national 
boundaries-are accompanied by self-negation processes, which sooner or later undermine too ambitious and universal visions of one's own and the global future. The unavoidable negative result of attempts at an intentionally final self-fulfilment of Russia and Russians intensifies in turn the need to look for new formulas, which are however condemned to repeat the fate of the previous ones, etc...

In the context of the above discussion, the rebirth, permanently observed in Russia, of the attempts to define its own identity, their recognizable, even automatic presence during consideration of the most concrete and specific matters, and also the amounts of intellectual, cultural and social energy consumed by those attempts become understandable: "Presumably, none other nation of the world-declares, not without grounds, American scholar in Russia studies, James Billington - has used up so much intellectual energy to answer to this question (related to the question of definition of own national identity-M. B.), as nation of Russia” (Billington, 2005: p. 26). The discomfort of many Russians towards themselves-related to questions of who they are, whom they should be, and what they bring to the world-often covered under the self-confident mask displayed to the outside world-also becomes more understandable. Multiple developing mechanisms and forms of "false conscience”, which accompany the Russian self-defining efforts, also become clear. This conscience is described as "false", because an unprejudiced analysis recognizes and as a consequence largely extends the sphere of the Russian commonwealth as a community searching for its own identity, a community of persistent attempts to find itself. It is not necessary to limit it (and therefore, de facto, restrain and divide) to the circle of persons or groups who declare the same exclusive, presumably full and integral, Truth (d'Encausse, 1988: p. 381)—and express the wish to embody it in social life from the position of its sole owner.

The indicated redefinition of the method of perceiving one's own identity, understanding one's own national community and its sense of existence, Russia and the people themselves, would undoubtedly widen the space for an openness of the Russian outlook on the world, the area of possible co-searching and co-creation, compromise and dialogue, both within the scale of their own, national, cultural, social and political community, and outside of it, among the others in the world.

\section{Conclusions}

When Dostoevsky's compatriots understand the subjective sense, character and results of similar attempts, and also the reasons and conditions for their vitality and significance in their national tradition, this would not have to lead to a separation from their roots. On the contrary, it would allow one to maintain a dialogue-based liaison with such a tradition, deepen their self-awareness, to create a "space" of distance and freedom, and to understand that the answer sought by the Russians asking about Russia in fact each time pertains to themselves. Thus, it could help them to develop a transcendent, epistemological point of view (in place of the previous epistemic point of view, directly intertwined with its own, specific cognitive relation with the presumed being) and as an effect-to understand better-in individual/existential sense and in the socio-cultural sense- who the persons asking about Russia in an indicated manner are, why they do so, what they would like to achieve, why they cannot definitively reach their goal and why they never stop to reiterate the efforts: to ask about Russia, to ask about themselves... The self-discovery, perceived as absolute in the Russian intellectual and cultural tradition and viewed in an imperative manner, would turn into self-understanding, conscious of its historical, relative, processual, dialogue qualities, etc.

In the final words I would like to notice that the formula "asking about Russia (and therefore, in the perspective proposed in the article, also about its manner of asking about Russia), asking about oneself" maintains its heuristic sense not only in relation to the thinkers or dwellers of Dostoevsky's motherland, asking about their country and the presumed nature of Russianness. It can be also applied to foreign thinkers, scholars and observers, who try to reflect upon Russianness or self-cognitive attempts made in Russia. How they conduct their research, what assumptions, model, theoretical schemes, methodological rules etc. they assume-those conditions define their status and scientific identity, although without the equally generalized, fundamental and existential sense, as in case of Russians themselves. Instead of: "tell me how you ask about Russia, and I will tell you who you are", the question is only-and as much as- "tell me how you research Russia, and I will tell you what scholar you are, and what you really do".

\section{References}

Andreev, N. (1970). Studies in Moscow. Western Influence and Bizantine Inheritance. London: Variorum Reprints. 
Billington, Dż. (2005). Rossija w poiskach siebia. Moskva: Rossijskaja politiczeskaja enciklopedija.

Broda, M. (2002). Paradoksy rosyjskiej wyobraźni. Ku rzeczywistości-Poza rzeczywistość. In G. Giesemann, \& T. Stepnowska (Eds.), Literaturwissenschaftliche und linguistische Forschungsaspekte der phantastischen Literatur. Frankfurt am Main: Herbert Utz Verlag.

Broda, M. (1998). Poniat’ Rossiju? Moskva: Dialog-MGU.

Broda, M. (2001). Historia a eschatologia. Studia nad myśla Konstantego Leontiewa i „zagadka Rosji”. Łódź: Wydawnictwo Uniwersytetu Łódzkiego.

Broda, M. (2003). Narodnickie ambiwalencje. Między apoteoza ludu a terrorem. Łódź: Ibidem.

Broda, M. (2005). Russkije voprosy o Rossii. Moskva: MAKS Press.

Broda, M. (2007). Mentalność, tradycja i bolszewicko-komunistyczne doświadczenia Rosji. Łódź: Ibidem.

Cirlot, J. E. (1971). Słownik symboli. Kraków: ZNAK.

d’Encausse, H. C. (1988). Le malheur russe. Essai sur le meurtre politique. Paris: Librairie Arheme Fayard.

Dostojewski, F. M. (1982). Dziennik pisarza, Vol. 3. Warszawa: Państwowy Instytut Wydawniczy.

Dostojewski, F. M.(1971). Z notatników. Warszawa: Państwowy Instytut Wydawniczy.

Faryno, J. (2001). Thinker, Thought, Reflexion. In A. de Lazari (Ed.), Idiei w Rossii. Idee w Rosji. Ideas in Russia. Leksykon, Vol. 4 (pp. 379-383) . Łódź: Ibidem.

Kelly, A. (1978). Introduction: Complex Vision. In I. Berlin (Ed.), Russian Thinkers. London: Hogarth Press.

Kołakowski, L. (1998). Jeśli Boga nie ma.... Kraków: ZNAK.

Ryabov, O. V. (1998). «Umom Rossiju nie poniat’... » Giendiernyj aspiekt „russkoj zagadki”, „Żenszczina w rossijskom obszczestvie”, No. 1 (pp. 32-46).

Sarnowski, S. (1982). Rozumność i świat. Próba wprowadzenia do filozofii. Warszawa: Państwowe Wydawnictwo Naukowe.

Serafim, S. (1992). Russkaja idieołogija. Sankt-Pietierburg: Izdatelstvo imieni A. S. Suvorina.

Siemek, M. (1982). Filozofia, dialektyka, rzeczywistość. Warszawa: Państwowy Instytut Wydawniczy.

Solov'ev, V. M. (2001). Tajny russkoj duszy. Voprosy, otviety, viersii. Moskva: Russkij jazyk. Kursy.

Solov'ev, V. S. (1991). Russkaja idieja. Sankt-Petierburg: Nauka.

Solov’ev, V. S. (1994). Cztenija o bogoczełovieczestvie. Sankt-Pietierburg: Chudozestvennaja literatura.

Strada, V. (1996). S svietie konca, v priedviesti naczała. In E. Rudnicksja (Ed.), V razdumiach o Rossii (pp. 23-41). Moskwa: Archeograficzeskij centr.

Sutton, J. (1988). The Religiosus Philosophy of Vladimir Solovyov. Hong Kong: Chines University Press. 
Scientific Research Publishing (SCIRP) is one of the largest Open Access journal publishers. It is currently publishing more than 200 open access, online, peer-reviewed journals covering a wide range of academic disciplines. SCIRP serves the worldwide academic communities and contributes to the progress and application of science with its publication.

Other selected journals from SCIRP are listed as below. Submit your manuscript to us via either submit@scirp.org or Online Submission Portal.
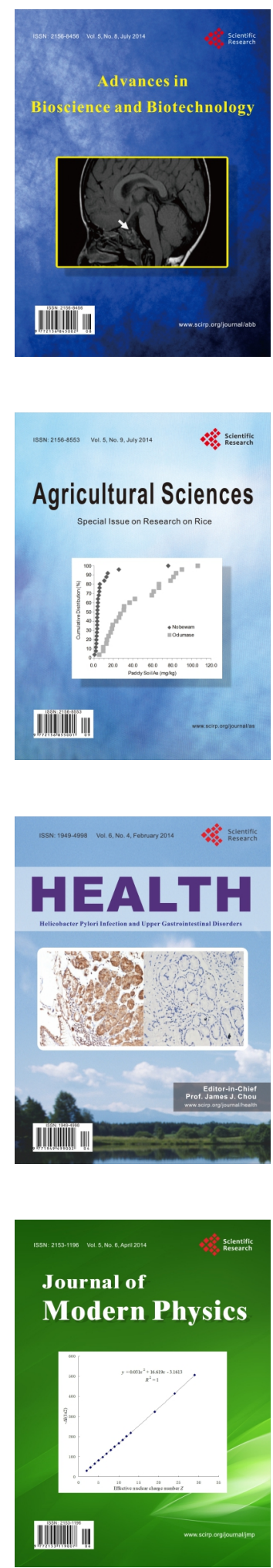
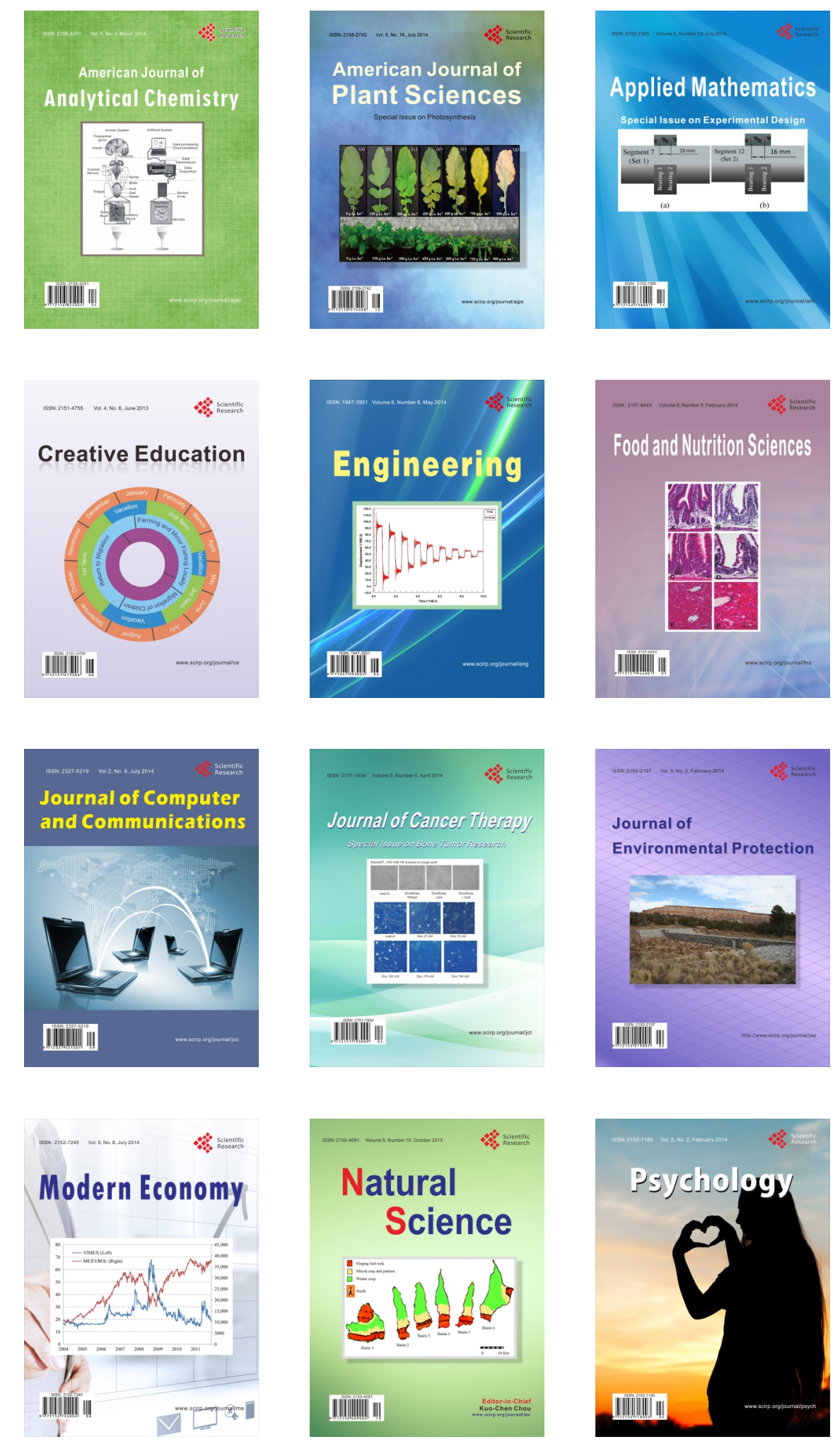